\title{
MODAL AWAL MENGEMBANGKAN WISATA DESA: PENGETAHUAN KESEJARAHAN, PERSEPSI, DAN PARTISIPASI MASYARAKAT PADA SITUS PETILASAN GADJAH MADA DI DESA LAMBANG KUNING
}

\section{(EARLY CAPITAL DEVELOPING VILLAGE TOURISM: HISTORICAL KNOWLEDGE, PERCEPTION, AND COMMUNITY PARTICIPATION ON GADJAH MADA SITE IN LAMBANG KUNING VILLAGE)}

\author{
Samidi M Baskoro', Sarkawi B Husain ${ }^{2}$, dan Ikhsan Rosyid Mujahidul Anwari ${ }^{3}$ \\ ${ }^{1,2,3}$ Departemen Ilmu Sejarah Fakultas Ilmu Budaya Universitas Airlangga \\ e-mail: sambaskoro@gmail.com
}

\begin{abstract}
The past is present today through cultural heritage (historical heritage sites), but some ordinary people do not know the importance of the value of these objects, as evidenced by the trade in fragments of artifacts. This action is driven by economic motives and has no knowledge of historical objects. The main problem is how to build knowledge and awareness of historical heritage objects? The answer to this problem can be the elements used as initial capital to develop village tourism. The main value of the development of village tourism is the creation of public spaces where people can relax and gather at leisure. The development of village tourism should not be driven by economic motives that are often echoed by various parties. The methods used to elaborate are observation, in-depth interviews to find collective memory, and counseling or workshops. The findings obtained from observations, interviews, and literature studies are the use of historical sites as a destination for village tourism must be supported by the prerequisites for development, namely the knowledge of local communities on the site will foster awareness of historical heritage, uniformity of perception about the function of the site not for religious purposes, and participation community in site preservation.
\end{abstract}

Keywords: historical relics, historical awareness, village tourism

\begin{abstract}
abstrak
Masa lalu adalah masa kini yang hadir melalui warisan budaya (situs peninggalan sejarah), tetapi sebagian masyarakat awam tidak mengetahui pentingnya nilai benda-benda ini, terbukti dari adanya perdagangan serpihan artefak. Tindakan ini didorong oleh motif ekonomi dan tidak memiliki pengetahuan pada benda-benda sejarah. Pokok permasalahan adalah bagaimana upaya membangun pengetahuan dan kesadaran pada benda-benda peninggalan sejarah? Jawaban persoalan ini dapat menjadi unsur-unsur yang digunakan sebagai modal awal mengembangkan wisata desa. Nilai pokok pengembangan wisata desa adalah penciptaan ruang publik tempat bersantai dan berkumpul bagi anggota masyarakat setempat pada waktu senggang. Pengembangan wisata desa tidak harus didorong oleh motif ekonomi yang seringkali digaungkan oleh berbagai pihak. Metode yang digunakan untuk menguraikan adalah observasi, wawancara mendalam untuk menemukan memori kolektif, dan penyuluhan atau workshop. Temuan yang diperoleh dari observasi, wawancara, dan studi literatur adalah pemanfaatan situs sejarah sebagai destiasi wisata desa harus didukung oleh prasyarat pengembangan, yakni pengetahuan masyarakat lokal pada situs akan menumbuhkan kesadaran pada peninggalan sejarah, penyeragaman persepsi mengenai fungsi situs bukan untuk kepentingan religi, dan partisipasi masyarakat dalam pelestarian situs.
\end{abstract}

Kata kunci: peninggalan sejarah, kesadaran sejarah, wisata desa 


\section{PENDAHULUAN}

Realita masa lampau dihadirkan dimasa kini melalui ceritadan tulisan. Cerita yang disampaikan secara berkelanjutan atau estafet antar generasi pada akhirnya dikenal dengan sebutan cerita rakyat yang tidak diketahui sumbernya. Rujukan yang seringkali muncul adalah menurut orang tua atau sesepuh. Meskipun demikian, cerita lisan atau cerita rakyat menjadi pengetahuan kolektif yang dianggap bermuatan historis oleh sebagian besar masyarakat. Proses pewarisan yang demikian panjang seringkali mengalami distorsi karena memungkinkan adanya pencampuran unsur-unsur peristiwa yang tidak nyata (irasional atau tidak masuk akal) menjadi kesatuan bagian bersama kenyataan. Hal ini dipengaruhi oleh pemikiran yang religio-magis dan kepercayaan pada mitos yang berlebihan. Penyampaian informasi secara lisan dari generasi ke generasi juga ikut berpengaruh menggerusmuatan faktual. Supaya tidak terjadi hal demikian, bahkan hilangnya cerita lisan, upaya penyelamatan cerita lisan dapat dilakukan melalui pendokumentasian dalam rupa rekaman dan tulisan. Pekerjaan ini dapat dilakukan terutama oleh kelompok pencinta sejarah, mahasiswa, dan cendikiawan atau intelektual (akademisi).

Pendokumentasian setidaknya mampu memperpanjang ingatan kolektif tentang peristiwa dan fenomena untuk memenuhi penulisan sejarah lokal. Sumber sejarah lokal juga dapat dilakukan melalui perawatan dan pelestarian berbagai peninggalan sejarah, seperti candi, masjid kuno, bangunan kuno, prasasti, arca, pundèn, dan serpihan gerabah kuno. Berbagai benda inisecara terminologis disebut benda cagar budaya yang pengaturan pelestariannya telah dilakukan sejak masa pemerintahan Hindia Belanda, kemudian diubah sesuai perkembangan zaman (UU No. 11/2010). Pembelajaran yang diperoleh dariartefak atau peninggalan budaya (cultural heritage) adalah semua lapisan masyarakat dapat mengembarakan imajinasi historis melalui penekanan bahwabendabenda peninggalan diupayakan dan diciptakan dengan tenaga dan pikiran (Santoso, 2017).

Dua hal yang telah disebutkan, yakni cerita lisandan peninggalan artefak,dapat digunakan oleh masyarakat lokal sebagai landasan membangun identitaslokal dan penguatan kesadaran historis. Akan tetapi, masyarakat lokal dalam lingkup administratif desa seringkali tidak mampu menunjukkan bukti-bukti sejarah, sehingga upaya rekonstruksi sejarah mengalami kesulitan. Hal ini dialami oleh sebagian besar desa di Jawa. Pada umumnya, sejarah asal-usul desa tidak dapat dilacak meskipundisinyalir telah lama terbentuk. Karya Prapanca, Negarakretagama atau juga disebut Desawarnana, menyebutkan beberapa desa dilalui oleh Hayam Wuruk pada saat berkunjung ke Lumajang pada tahun 1359 (Sidomulyo, 2017), tetapi ketiadaan sumber tertulis yang menyebabkan sejarah mikro desa yang telah lama terbentuk sulit direkonstruksi. Demikian juga dengan Desa Lambang Kuning, Kecamatan Kertosono, Kabupaten Nganjuk, yang memiliki peninggalan atau situs sejarah. Konsensus masyarakat setempat menyebutnya Petilasan Gadjah Mada merupakanartefak (benda cagar budaya)yang penjelasannya tidak hanya tertuju pada benda yang tampak, tetapi juga cerita-cerita dibalik benda.

Penduduk Desa Lambang Kuning mengalami situasi keterputusan cerita (missing link) ketika menyampaikan sejarah desa dan keberadaan situs ini yang diyakini telah muncul sejak zaman Majapahit. Oleh karena kondisi terbengkalai selama ratusan tahun menyebabkan keberadaannya dianggap angker. Jumlah penduduk yang meningkat dari 
waktu ke waktu mengakibatkan munculnyapemukiman semakin padat di sekitar situs. Pandangan pun berubah, dan masyarakat tidak lagi menganggap angker.Beberapa orang berani berkunjung pada malam hari oleh orang dengan tujuan khusus ritual. Akan tetapi, persepsi yang berkembang setelah situs dikunjungi oleh orang yang datang dari luar desa adalah tindakan berkunjung dianggap sebagai upaya melestarikan, menghidupkan, dan membangkitkan tradisi lama yang tidak sesuai syariat Islam.

Situs sejarah di Desa Lambang Kuning merupakan benda cagar budaya yang berasal dari titik waktu/zaman Majapahit yang memunculkan perbedaan persepsi antara realitas dan imajinasi. Perbedaan ini terjadi pada masyarakat ketika mengamati dan menyampaikan cerita mengenai makam dan tumpukan batu-bata kuno. Penyematan nama petilasan Gadjahmada pada tumpukan batu-bata dan makam hanya upaya identifikasiatas dasar persepsi dan kesepakatan tanpa kepastian orang yang disemayamkan dan waktu pembangunan makam. Kajian arkeologis dan historis hanya mampu mengidentifikasi zaman berdasarkan bentuk dan corak material.

Huruf dan angka pada nisan makam tidak tercantum sehingga selalu memunculkan beberapa persepsi tanpa landasan realita. Pada akhirnya, kebenaran tentang orang yang disemayamkan adalah persepsi dan pemaknaan masyarakat setempat. Hal ini tidak hanya tertuju pada tumpukan batu-bata dan makam kuno di Desa Lambang Kuning, tetapi juga berbagai makam kuno lain di Jawa, contohnya adalah makam Joko Tingkir (Sultan Hadiwijaya) yang berlokasi di beberapa daerah, yakni Desa Pringgoboyo (Lamongan), Dusun Butuh (Sragen), Dusun Rawagede (Karawang), dan di beberapa tempat lain. Oleh karena itu, kebenaran identifikasi bersifat relatif (tidak mutlak). Perhatian tidak tertuju pada pemberian nama, tetapi pada pelestarian warisan budaya yang dilakukan oleh masyarakat lokal. Pengetahuan apa yang mereka warisi dari orang tua dan bagaimana persepsi masyarakat pada situs Petilasan Gadjah Mada?Tulisan ini tidak berupaya menjelaskan microhistory, artinya tidak mengulas asal-usul atau cikalbakal desa, tetapi difokuskan pada pewarisan pengetahuan kesejarahan, persepsi masyarakat, dan upaya pelestariansitus Petilasan Gadjah Mada(dianggap sebagai pundèn)?Unsur-unsur ini sebagai modal awal mengembangkan wisata desa berbasis situs.

\section{METODE PENGABDIAN MASYARAKAT}

Tulisan ini berangkat dari pengabdian, sehingga langkah awal yang dilakukan adalah menggali informasi kemudian dikembalikan lagi kepada mereka dalam kelompok diskusi (focus group discussion) sekaligus penyampaian materi-materi penyuluhan. Pada awalnya pendekatan yang dilakukan adalah kerjasama untukpenyelamatan, perlindungan, dan pelestarian. Pendekatan ini sebagai langkah awal menyamakan persepsi dan menumbuhkan kesadaran tentang objek (benda peninggalan sejarah) yang ditempuh melalui penggalian informasi yang meliputi observasi, wawancara mendalam, pengumpulan referensi, dan penyusunan laporan.

Wawancara dilakukan pada masyarakat yang tinggal di lingkungan sekitar peninggalan sejarah, tokoh-tokoh, pamong desa, dan pemuda. Wawancara difokuskan untuk menemukan memori kolektif, pengetahuan kesejarahan, persepsi, dan partisipasi yang terkait dengan benda peninggalan sejarah. Penulisan laporan tentu tidak cukup hanya mengandalkan hasil wawancara, karena itu referensi serupa menjadi rujukan untuk menyusun kerangka pikiran. 
Kedua adalah penyuluhan pengelolaan aset desa sebagai objek wisataberbasiskan peninggalan sejarah yang dikemas dalam forum diskusi. Materi pokok adalah manfaat sejarah dan sejarah destinasi wisata desa berbasis peninggalan sejarah. Destinasi wisata desa adalah ruang publik masyarakat desa yang dikembangkan atau diciptakan melalui potensi yang sudah ada. Nilai pokok pengembangan wisata desa adalah penciptaan ruang publik tempat bersantai dan berkumpul bagi masyarakat di sela-sela waktu senggang.Langkah kedua ini merupakan materi-materi yang disampaikan oleh ahli sebagai masukan dan pertimbangan untuk menyusunan tulisan ini.

Peserta/unsur yang terlibat atau hadir dalam kegiatan adalahmasyarakat, perangkat Desa Lambang Kuning dan Tim Pengabdian kepada Masyarakat dari Universitas Airlangga. Kegiatan ini selain umpan balik dengan cara menyampaikan materi terkait pandanganpandangan teoretis optimalisasi potensi desa, dan menjaring kembali infomasi terkait situs.

\section{HASIL DAN PEMBAHASAN}

\section{Pengetahuan Mengenai Situs Lambang Kuning}

Istilah pundèn pada masanya merupakan wujud bangunan tumpukan batu yang secara fungsional bermakna mendalam untuk mendekatkan diri pada sang pencipta. Bangunan yang dianggap oleh masyarakat sebagai pundèn merupakan bukti peradaban yang usianya lebih panjang dari mereka yang menyusunnya. Lingkungan di sekitarnya bukanlah tempat sunyi senyap yang hanya berani dikunjungi oleh para pencari nilainilai spiritual melalui prosesi lelaku, tetapi telah menyatu dengan beragam aktivitas masyarakat desa terlebih pada saat penyelenggaraan upacara atau peringatan tertentu. Upacara desa sebagai bagian dari tradisi yang sampai saat ini diselenggarakan bersih desa (nyadran).

Lokasi di sekitar situsLambang Kuning pada masa itu tentu berpenghuni karena ditandai oleh sisa-sisa perabotan, tempat ibadah, dan pemakaman.Makam adalah tempat menyimpan atau mengubur jenazah, dan masyarakat Jawamenyebut kuburan, yang diduga berasal dari kata qabr (bahasa Arab). Jika jenazah yang dikubur itu adalah tetua atau tokoh desa yang dihormati ditempatkan tersendiri. Selain istilah tersebut, orang Jawa juga mengenal pasarean, yang artinya juga tempat mengubur jenazah. Istilah pasarean berasal dari kata sare artinya tidur. Bahasa Sanskerta memiliki istilah stha (kemudian berubah menjadi asthana) mempunyai arti yang sama dengan istilah yang telah disebutkan, yang arti harafiahnya adalah tinggal, diam, istirahat. Kuburan, pasarean, stha, astana bagi seorang tokoh tidak sekadar tempat 'sare', tetapi juga tempat yang dikeramatkan atau disakralkan oleh generasi berikutnya. Kesakralan berkaitan dengan hal-hal yang penuh misteri baik yang mengagumkan ataupun yang menakutkan.

Situs Petilasan Gadjah Mada menunjukkan karakteristik pasarean tokoh sekaligus pundèn yang terletak di Desa Lambang Kuning, salah satu dari 13 desa Kecamatan Kertosono, Nganjuk. Berdasarkan data statistik desa, Kabupaten Nganjuk memiliki 264 desa pada tahun 2017(https://nganjukkab.bps.go.id). Di antara jumlah desa tersebut, diduga ada yang telah terbentuk pada beberapa abad yang lalu, bahkan sejak Pu Sindok (929 - 947 M) memindahkan kerajaan yang berkedudukan di Tamwlang, kemudian di Watugaluh, wilayah Jombang (Sumadio, 1992). Sebaran desa kuna di wilayah Nganjuk memang tidak terindentifikasi, tetapi berdasarkan bukti temuan prasasti Anjukladang 
(tahun $937 \mathrm{M}$ ) menunjukkan wanua (masyarakat desa) dan penganugerahan penetapan sima (sebidang tanah yang dibebaskan pajak dan kewajiban-kewajiban lain). Pada masa $\mathrm{Pu}$ Sindok, sebagian besar prasasti yang ditetapkan berkenaan dengan bangunan suci atas permintaan rakyat desa dan atas perintah raja (Sumadio, 1992). Dengan demikian, pemukiman-pemukiman sudah ada pada saat itu, meskipun kajian khusus tentang desa tidak ditemukan.

Lambang Kuning yang terletak tidak jauh ke arah barat dari Sungai Brantas diduga sudah terbentuk dan berpenghuni sejak masa Majapahit yang dibuktikan oleh situs pesarean kuno (pundèn), sisa-sisa pondasi kuna, dan berbagai pecahan gerabah-keramik yang tersebar di lahan persawahan.Perwujudan pundèn berupa tumpukan atau tatanan batu-bata yang disusun melingkar dan bertingkat-tingkat (berundak). Oleh karena itu, situs ini dahulu digunakan sebagai tempat untuk penyimpanan abu jenazah atau memang untuk mengubur jenazah yang tidak diketahui orang yang disemayamkan. Sebagian masyarakat mewarisi pengetahuan dari leluhurnya bahwa situs ini sebagai warisan Mbah Budo. Akan tetapi, ada juga sebagian masyarakat setempat menyebut situs dengan nama Petilasan Gadjah Mada. Istilah petilasan atau tilasan, artinya peninggalan atau tinggalan, yakni sesuatu berupa benda peninggalan (Ahimsa-Putra, 2004). Dengan demikian, Petilasan Gadjah Mada yang memiliki perwujudan pesarean bukan tempat dikuburnya patih Gadjah Mada.

Bukti historis yang bersumber dari Kitab Negarakretagama karya Prapanca menyebutkan kematian Gadjah Mada pada tahun 1364 M. Peranannya mulai dikenal dan dicatat dalam sejarah ketika memimpin pasukan Bayangkara kerajaan Majapahit menyelamatkan Raja Jayanegara dari pemberontakan Kuti yang menguasai istana. Nama Gadjah Mada semakin populer saat menduduki jabatan sebagai patih sejak tahun $1334 \mathrm{M}$ dan dianggap mampu mewujudkan sumpahnya memperluas wilayah kerajaan Majapahit tidak hanya dalam lingkup Jawa (Sumadio, 1992; Sidomulyo, 2017; Slametmulyana, 1979). Di sisi lain, Gadjah Mada dikenal sebagai penyebab gagalnya perkawinan Hayam Wuruk dan Dyah Pitaloka karena calon istri peserta pengiringnya gugur dalam peristiwa Bubat. Berdasarkan Pararaton, peristiwa ini terjadi pada tahun 1279 Saka atau 1357 Masehi. Dari Kidung Sundayana diketahui bahwa peristiwa ini yang menyebabkan Gadjah Mada meninggalkan kerajaan Majapahit, tetapi tidak sesuai tahun peristiwa (Muljono, 1965).

Menurut cerita rakyat yang berkembang di antara para sesepuh desa disebutkan bahwa Gadjah Mada pernah meninggalkan pusat kerajaan Majapahit untuk mengasingkan diri di sebelah Sungai Brantas di Dusun Karang Kletak (Lambang Kuning) setelah peristiwa Bubat. Perdikan ini merupakan tempat tinggal Ratu Niang atau Roro Kuning atau Rondo Kuning yang kemudian dikenal sebagai istri Gadjah Mada. Penyampaian kisah ini tidak berarti membenarkan atau menolak peristiwa, tetapi demikianlah cerita rakyat yang disampaikan secara turun-temurun sehingga masyarakat memutuskan konsensus untuk memberi identitas situs.

Menurut kesaksian Sumalianto yang sejak masa muda memberanikan diri merawat situs dengan cara membersihkan sampah daun yang berguguran di area yang dikenal angker. Di area situs tumbuh pohon Puring yang tidak pernah besar, dan tinggi tumpukan batubata mengalami penyusutan. Selain itu, dia menyatakan pernah menemukan batu-bata bertuliskan angka 1362 (Wawancara dengn Sumalianto). Mengenai keangkeran lokasi situs dibenarkan oleh penduduk Desa Lambang Kuning, tetapi pernyataan tentang 
pohon Puring dan perubahan ketinggian bersifat subjektif yang tentunya harus dipahami melalui argumentasi logis sebab akibat dari kondisi. Penyebutan angka tahun 1362 tidak dijelaskan tarikh tahun saka atau masehi. Jika tahun itu bertarikh saka, maka konversi ke tahun masehi adalah 1440. Apabila angka tahun 1362 merujuk masehi, berarti berkesesuaian dengan masa hidup Gadjah Mada. Hal ini dapat dirujuk berdasarkan Kitab Negarakretagama yang menyebutkan kematian Gadjah Mada pada tahun 1364 M.

Realitas lain mengenai tumpukan batu-bata yang dapat diamati adalah bekas pondasi batu-bata kuno di pematang sawah yang berjarak 500 meter dari situspundèn.Pondasi ini membentuk bidang datar persegi panjang yang diduga terintegrasi dengan situs. Di dalam area itu terdapat serpihan gerabah (Jawa: kreweng), keramik kuno, dan lingga (bentuk seperti lumpang) sebagai buktibahwa tempat ini sebagai area pemukiman. Menurut Tarmo (lahir tahun 1950-an), yang mendapatkan cerita lisan dari leluhurnya, dikatakan bahwa eyang buyutnya pernah tinggal ditempat itu. Kini, areal ini menjadi lahan pertanian. Warga masyarakat tidak mampu mengatakan waktu peralihan fungsi lahan pemukiman menjadi areal persawahan.Dua situs sejarah ini menunjukkan kontradiksi, yakni situs Petilasan Gadjahmada masih ada wujudnya, sementara yang lain terkubur dan berserakan.

Perwujudan tumpukan batu bata dapat dilihat dan disentuh, tetapi yang dianggap sakral ini juga mempunyai aspek yang tidak kelihatan dan gaib yang diyakini dengan wujud berbagai macam, seperti jin, dedemit, sebagai penunggu atau penjaga situs. Pada tahun 1950-an, Petilasan Gadjah Mada masih dianggap sebagai tempat yang angker, sehingga anggota masyarakat tidak memiliki keberanian untuk datang apalagi melakukan kegiatan di tempat ini. Sumarlan juga meyakini bahwa situs ini bukan tempat pemakaman Gadjah Mada, tetapi hanya peninggalan, atau sebagai tempat yang pernah disinggahi dan dihuni dalam waktu tidak tentu. Lambat laun, situs ini dijadikan sebagai pundèn karena perwujudan tatanan batu-bata yang disusun berundak-undak. Menurut cerita lisan, ada kera putih yang hidup liar di pepohonan (Wawancara dengan Sumarlan). Penyampaian kisah ini bukan atas dasar kebenaran, tetapi memang demikian yang ada di dalam pikiran. Maka, realitasnya terletak pada kepercayaan masyarakat bukan pada makhluk tak kasatmata.

Keangkeran situs sudah berkurang drastis ketika masyarakat melakukan perawatan dan pemerintah kabupaten Nganjuk memberi perhatian.Pemerintah daerah bekerjasama dengan yayasan Kertagama Jakarta menyebut dengan istilah dipugar yang diresmikan pada 29 November 2008. Peran aktif penduduk desa tentu tidak dikesampingkan dengan cara mengubah di sekitar situs menjadi ruang publik.

\section{Menyamakan Persepsi Fungsi Situs}

Kunjungan ke situs-situs bersejarah dan tempat makam kramat/kuno oleh sebagian masyarakat Jawa memiliki beberapa tujuanyang bersifat sakral maupun profan, seperti memanjatkan doa, refleksi diri, mengetahui tokoh, dan plesiran. Dorongan lain yang tersembunyi adalah keinginan mendapatkan sesuatuterkait dengan keyakinan-keyakinan adanya pengaruh-pengaruh tertentu jika dilakukan ritual khusus di tempat tersebut. Daya tarik untuk berkunjung ke tempat ini bagi sebagian orang bukan didorong oleh keingintahuan yang besar pada sejarah suatu tempat, tetapi ccnderung ingin mendapatkan sesuatu dari keunggulan tokoh. Oleh karena itu, sesuatu yang diinginkan adalah berkah. Masing-masing pengunjung memiliki motif yang ada di dalam batin, 
sehingga bagian ini tidak diketahui oleh orang lain. Cerita yang disampaikan oleh penduduk sekitar Petilasan Gadjah Mada memunculkan kisah spiritual tertuju pada pengunjung.

Situs yang masih tersisa utuh atau sebagian merupakan bukti zaman atau bukti sejarah yang bermanfaat sebagai media pembelajaran secara langsung untuk bidang sejarah lokal atau bidang budaya. Masyarakat lokal dapat memanfaatkan situs sebagai bukti bahwa lingkungan yang mereka huni merupakan warisan nenek moyang. Apabila masyarakat setempat meyakini situs sebagai Petilasan Gadjah Mada, berarti secara tidak langsung membenarkan adanya kesinambungan zaman dari Majapahit (1294-1527 M) sampai kini. Hal ini digunakan sebagai penguat identitas bahwa perbedaan dan perubahan merupakan keniscayaan dalam hidup bermasyarakat.

Sebagian tradisi masih dipertahankan oleh penduduk Desa Lambang Kuning yang asalusulnya dari zaman Majapahit adalah tradisi Nyadran. Bahkan, tradisi Nyadran sampai saat ini masih dipraktikkan oleh sebagian besar masyarakat pedesaan di daerah Nganjuk. Tradisi ini juga diselenggarakan oleh seluruh pedusunan (bagian dari desa) di Kabupaten Nganjuk secara bergantian sebagai peristiwa budaya.Kepastian waktu tentang kapan nyadran pertama kali diselenggarakan oleh penduduk Desa Lambang Kuning tidak akan mampu dijawab atau tidak dapat dipastikan waktu nyadran pertama kali diselenggarakan oleh setiap desa. Akan tetapi, nilai pokok dari tradisi yang masih berlanjut terletak pada kesimungan dan solidaritas.

Kesinambungan bermakna masih berlanjut sampai saat ini yang asalnya dari generasi terdahulu. Tradiis nyadran merupakan aktivitas budaya yang asal-usulnya dapat dihubungkan dengan peristiwa sadhrayang diselenggarakan pada masa Raja Hayam Wuruk. Dengan demikian, nilai yang diajarkan pada masa Majapahit tidak bertentangan dengan nilai-nilai yang berlaku pada saat ini. Bagian-bagian yang sedikit diubah hanya pada ritual atau kesakralan disesuaikan dengan keyakinan yang dianut oleh masyarakat. Dengan demikian, masyarakat hanya menjalankan tradisi sebagai wujud kebersamaan (solidaritas) yang diwarisi secara turun-temurun.

Kegiatan budaya ini masih dipraktikkan karena memiliki akar historis. Peristiwa budaya yang disebut Nyadran berasal dari ritual keagamaan yang terkait dengan perilaku mengenang dan mendoakan orang yang telah meninggal dunia. Berdasarkan karya Prapanca (nama samaran), Negarakretagama, dipupuh 63-67 menyinggung tentang pesta sradhha pada tahun $1362 \mathrm{M}$. Perubahan kata sadhra menjadi nyadran menunjukan proses gramatikal berupa pemberian imbuhan atau akhiran dan perubahan bunyi dalam ungkapan bahasa Jawa. Makna yang dimaksudkan pada dua kata tersebut dianggap sama, yakni peristiwa budaya yang berhubungan dengan mengenang lelulur melalui prosesi yang disepakati oleh masyarakat lokal.

Prapanca menjadi saksi atas peristiwa Sradhha sebelum dia mengasingkan diri untuk mengarang kitab tersebut pada tahun 1365 M. Karya lain yang menyebut pesta sradhha terdapat di Pararaton.

"mengenai pesta srada, Pararaton hanja menjinggung dalam satu baris sadja. Beritanja terlalu singkatdan hanja menjebut bahwa prabu Hajam Wuruk pada tahun Saka 1284 mengadakan pesta srada." (Muljono, 1965) 
Awal mula upacara sradha atas permintaan Tribhuwanatunggadewi kepada Hayam Wuruk untuk melakukan penghormatan pada neneknya, Rajapatni Gayatri, yang meninggal pada $1350 \mathrm{M}$. Mengenai penyelenggaraan pesta sradha dideskripsikan pada kutipan berikut.

"Upatjara dimulai pada hari jang pertama dengan pemudjaan Buda. Semua pendeta berdiri dalam lingkaran untuk menjaksikan pemudjaan Buda oleh baginda. Pada malam berikutnja dilakukan pemudjaan pada artja bunga [.....]. Paginja artja bunga dibawa keluar, disambut dengan bunji tambur dan genderang. Sehabis pemudjaan [.....] tampil dihidangan makanan jang sedap dan nikmat. Setiap hari dihidangkan sadjian makanan jang sedap-sedap. Selama tudjuh hari tudjuh malamkota Madjapahit dibandjiri orang dari segala pelosok. Mereka datang berdujun-dujun untuk menjaksikan apa jang terjadi jang paling besar sampai pada saat itu. Setiap hari selalu ada pertundjukan. Atjaranja setiap hari berganti, njanjian, tari-tarian, perang-tanding, wajang, topeng, dan sebagainya.(Muljono, 1965)

Upacara sradha menggabungkan ritual bersifat sakral dilanjutkan pesta yang profan. Tradisi nyadran yang telah diselenggarakan sejak ratusan tahun diduga berkaitan dengan sradha. Tradisi nyadran adalah peristiwa budaya yang dapat dikemas untuk diintegrasikan dengan keberadaan situs.

\section{Partisipasi Masyarakat Dalam Pelestarian}

Bentuk perhatian pada situs tentu dibedakan berdasarkan partisipasi.Situs Petilasan Gadjah Mada masih mendapat perhatian dari masyarakat setempat yang dibuktikan dengan adanya pemagaran untuk tujuan perlindungan. Pada awalnya, pagar dibuat dari kayu dan bambuyang lapuk seiring dengan waktu, tetapi perlindungan berupa pagar yang lebih kokoh dibangun pada tahun 2008 atas usul berbagai pihak di Desa Lambang Kuning. Pemagaran tentu tidak dimaksudkan untuk mengisolasi situs dari keseharian masyarakat. Area relatif luas di sekitar situs yang menjadi aset desa belum dimanfaatkan secara maksimal untuk mendukung melengkapi fasilitas ruang publik. Partisipasi masyarakat dapat didorong untuk mengupayakannya supaya gagasan situs sejarah sebagai objek wisata terwujud.

Partisipasi yang selama ini telah dilakukan oleh masyarakat sekitar berupa perawatan dengan cara membersihkan daun-daun berserakan secara berkala. Pengerasan jalan berupa paving sebagai akses menuju situs juga memadai, namun kekurangannya lebar jalan masih sempit karena ruasjalan hanya selebar mobil yang tak dapat berpapasan dengan sepeda motor dari arah berlawanan. Fasilitas pendukung berupa jamban, toilet, dan kursi panjang juga tersedia. Beberapa fasilitas ini memang disediakan pada pengunjung meskipun terkesan sederhana. Menurut sekretaris desa Lambang Kuning, pengunjung situs dapat mencapai ratusan orang pada waktu tertentu. Kedatangan pengunjung dengan beragam tujuan, seperti wisata tempat keramat (religi), wisata biasa, dan lelaku (menyepi dari keramaian).

Realitas lain yang menunjukkan optimalisasi potensi wisata desa adalah melalui pembenahan dan pengembangan tidak hanya pada hal fisik, tetapi juga kesamaan pemahaman. Identifikasi untuk pengembangan tertuju pada hal pokok terkait 
menyamakan persepsi tentang situs peninggalan masa Hindu Budha. Sebagian masyarakat Lambang Kuning memandang bahwa pelestarian situs Hindu Budha dianggap rencana membangkitkan kepercayaan/keyakinan Hindu. Pandangan ini perlu diluruskan dengan cara diskusi untuk menumbuhkan kesadaran masyarakat yang bertempat tinggal di sekitar situs. Dasar pemikiran revitalisasi situs bertujuan mempertahankan keberadaan situs supaya tidak hilang, pemenuhan ruang publik desa, dan pendidikan, bukan membenturkan keyakinan dengan praktik yang bertentangan.

Perhatian pada situs sejarah untuk pendidikan dan pembelajaran berimplikasi pada signifikansi perlindungan, perawatan, dan menampilkan keterangan tentang cerita/kisah sejarah situs. Situs sejarah akan lebih dimengerti oleh pengunjung apabila terdapat keterangan atau narasi yang menjelaskan tentang situs. Sementara itu, keterangan yang ada tidak dapat dibaca dengan mudah. Pengunjung khususnya peserta didik (murid SD, SMP, SMU) perlu mendapat informasi tentang situs sehingga mendapat pengetahuan dan memiliki kesadaran untuk tidak berbuat vandalistik, dan lebih luas lagi tentang pengetahuan sejarah lokal.

Peninggalan artefak berupa lumpang (menurut persepsi masyarakat setempat) hanya tersisa satu yang tertanam di pematang dan batu bata persegi empat berserakan. Menurut Tarmo, batu berbentuk lumpang atau batu-bata kuno yang berada di lahannya didaku (diakui sebagai milik pribadi) oleh pemilik lahan. Beberapa batu tersebut telah digali dan dipindahkan ke rumah pemilik sawah. Fakta ini menunjukkan ada ketidaktahuan tentang undang-undang benda cagar budaya dan kurangnya pemerintah lokal memberi wawasan tentang artefak. Oleh karena itu, menyamakan persepsi dan menumbuhkan kesadaran masyarakat pada benda peninggalan sifatnya urgen.

Menyikapi berbagai hal yang berhubungan dengan situs sebagaimana yang disebutkan di atas, sebagian masyarakat yang menaruh kepedulian pada peninggalan sejarah perlu untuk membentuk perkumpulan. Beberapa orang tua warga Desa Lambang Kuning memang telah membentuk Paguyuban Petilasan Mahapatih Gadjah Mada. Menurut Fathoni, salah satu sesepuh, menyebutkan bahwa kegiatan yang dilakukan oleh paguyuban ini adalah berkumpul untuk mocopatan dan istighosah. Pemaknaan atas kegiatan berkumpul merupakan wahana untuk komunikasi, memunculkan ide, dan menstimulasi kepedulian.

\section{PENUTUP}

\section{Simpulan dan Saran}

Peninggalan sejarah berupa situs dalam wilayah desa dimaknai secara khusus oleh masyarakat setempat sebagai warisan leluhur yang dianggap berhubungan dengan pendiri atau awal mula terbentuknya pemukiman. Pada awalnya, situs pundèn memiliki fungsi religi, tetapi seiring dengan terjadinya perubahan keyakinan masyarakat berakibat pada hilangnya praktik-praktik yang bersentuhan dengan situs. Lambat laun, keberadaan pundèntak terawat, terbengkalai, dan muncul persepsi keangkeran. Kondisi demikian tetap membuktikan bahwa keberadaan fisik atau artefak merepresentasikan nilai historis sebagai media pembelajaran. Selain itu, masyarakat lokal juga dapat memanfaatkan secara optimal sebagai akar penguatan identitas dan objek wisata desa. 
Pemanfaatan situs sejarah sebagai objek wisata desa harus didukung oleh prasyarat sebagai modal awal pengembangan, yakni pengetahuan masyarakat lokal pada situs, penyeragaman persepsi mengenai fungsi situs, dan partisipasi masyarakat dalam pelestarian situs. Prasyarat pertama harus dimiliki oleh masyarakat lokal atau sekelompok orang yang telah membekali diri dengan pengetahuan historis pada pada objek (situs). Pengetahuan historis harus dimiliki khususnya oleh pemandu wisata atau pramuwisata (tour guide) atau orang yang terlibat secara langsung.

Kedua, fungsi situs harus dipersepsikan sebagai objek wisata dan media pembelajaran sejarah. Menyeragaman atau menyamakan persepsi bertujuan membangun kesadaran dan kepedulian terhadap situs, sehingga benturan kepentingan dapat diminimalkan. Perbedaan persepsi pada peninggalan sejarah dapat berakibat pada aksi anarkistik (penghancuran), vandalistik, dan pencurian. Jika tindakan ini terjadi, akibat yang ditimbulkan adalah kerusakan bahkan kemusnahan. Anarkistik dan vandalistik dapat saja terjadi karena benturan keyakinan, sedangkan aksi pencurian terkait dengan nilai ekonomi pada benda peninggalan sejarah yang dapat diperjual-belikan.

Ketiga, partisipasi masyarakat tidak dapat dikesampingkan ketika muncul gagasan untuk menetapkan dan mewujudkan situs/peninggalan sejarah sebagai objek wisata. Partisipasi dapat dilakukan melalui aksi nyata membersihkan dan merawat situs. Mekanisme untuk perawatan dapat dilakukan oleh sebagian masyakat secara beriliran dan berkala. Selain itu, berbagai fasilitas yang dibutuhkan sebagai pendukung peninggalan sejarah sebagai objek wisata harus disediakan melalui sinergi antara masyarakat dan pemerintah desa. Ketiga prasyarat tersebut merupakan modal awal ketika berupaya mewujudkan objek sejarah sebagai wisata lingkup lokal.

\section{DAFTAR PUSTAKA}

Ahimsa-Putra, Heddy Shri (penyunting). 2004. Jejak Masa Lalu, Sejuta Warisan Budaya. Yogyakarta: Kunci Ilmu

Danandjaja, James.1991. Foklor Indonesia. Jakarta: Pustaka Utama Grafiti

https://nganjukkab.bps.go.id/statictable/2018/12/11/54/jumlah-desa-dan-jarak- dariibukota-kecamatan-ke-ibukota-kabupaten-di-kabupaten-nganjuk-km- 2017.html

Muljono, Slamet. 1965. Menudju Puntjak Kemegahan, Sedjarah Keradjaan Madjapahit. Jakarta: P.N. Balai Pustaka

Mulyana, Slamet. 1979. Nagarakretagama dan Tafsir Sejarahnya. Jakarta: Bhratara Karya Aksara

Santosa, Revianto Budi. 2017. Trusmi: Berarsitektur Yang Tak Abadi. Yogyakarta: Mata Bangsa

Sedyawati, Edi. 2007. Budaya Indonesia: Kajian Arkeologi, Seni, dan Sejarah. Jakarta: Raja Grafindo Pers

Sidomulyo, Hadi. 2007. Napak Tilas Perjalanan Mpu Prapanca. Jakarta: Wedatama Widya Sastra bekerjasama dengan Yayasan Nandiswara \& Jurusan Pendidikan Sejarah FIS Unessa 
Sumadio, Bambang (ed.). 1992. Sejarah Nasional Indonesia II: Jaman Kuna. Jakarta: Balai Pustaka

UU No 11 Tahun 2010 tentang Cagar Budaya

\section{Informan}

Sumarlan, 68 tahun

Sumalianto, 80 tahun 